\title{
Treatment of refractory epilepsy with the modified Atkins diet
}

\author{
María Magdalena Vaccarezza, M.D. ${ }^{a}$, Marisol Vanesa Toma, M.D. ${ }^{a}$, Juan David Ramos Guevara, M.D. ${ }^{b}$, \\ Cecilia Griselda Diez, M.D. ${ }^{c}$ and Guillermo Eduardo Agosta, M.D. ${ }^{a}$
}

\begin{abstract}
The modified Atkins diet (MAD) is an alternative therapeutic diet for the treatment of drug-resistant epilepsy. It consists of a diet with $60 \%$ energy from fat, $30 \%$ from protein, and $10 \%$ from carbohydrates. The objective of this article is to present a series of nine patients diagnosed with refractory epilepsy of different etiologies treated with the MAD at our hospital. In our group of nine patients, results obtained were similar to those published by other authors, with adequate adherence, tolerance and response. Of all patients, two achieved a reduction of more than $90 \%$ in the number of seizures; four experienced a reduction of $50-90 \%$; two had a reduction of less than $50 \%$ in seizure control; and only one patient did not respond to the MAD. No patient had an increase in the number of seizures, and the diet was well-tolerated in all cases.

Key words: refractory epilepsy, modified Atkins diet, ketogenic diet, tolerance, effectiveness.
\end{abstract}

http:/ /dx.doi.org/10.5546/aap.2014.eng.348

\section{INTRODUCTION}

Refractory epilepsy is a condition that occurs in approximately $30 \%$ of all patients with epilepsy. ${ }^{1}$ It is defined as the lack of response to two treatment schedules (adequate and welltolerated), either as monotherapy or combined, so that patients are continuously seizure-free.

The classic ketogenic diet (CKD) is an alternative therapeutic diet that has been used for more than 90 years for the treatment of drug-resistant epilepsy. ${ }^{2}$ The CKD may have an anticonvulsant effect by means of specific mechanisms of action on neurotransmitters and

a. Division of Pediatric Neurology. Hospital Italiano de Buenos Aires, Argentina.

b. Department of Neuropediatrics. Fundación Hospital de la Misericordia. Universidad Nacional de Colombia. Bogotá, Colombia.

c. Division of Clinical Pediatrics. Hospital Italiano de Buenos Aires, Argentina.

E-mail Address:

María Magdalena Vaccarezza:

maria.vaccarezza@hospitalitaliano.org.ar

Conflict of interest: None.

Received: 3-27-2013

Accepted: 2-5-2014 metabolites. ${ }^{3}$ The CKD is a strict diet where $90 \%$ of energy comes from fat, occasionally leading to difficulties with compliance and adherence. ${ }^{4}$

The Atkins diet was developed in the 1970s by Dr. Robert Atkins for the treatment of obesity. It was formulated as a high fat diet with a variable carbohydrate intake depending on the patient's weight.

At the end of the 1990s, the modified Atkins diet (MAD) was developed, with an adequate calorie intake distributed as follows: $60 \%$ fat, 30\% protein, and $10 \%$ carbohydrates, with no protein restriction, therefore making its adherence and tolerance easier for patients. ${ }^{4-6}$ In 2008, the results of the first randomized, controlled study were published, which described the effectiveness of the ketogenic diet as a treatment for refractory epilepsy in the pediatric and adult populations. ${ }^{7}$

\section{DESCRIPTION OF CASES}

A series of cases of children with refractory epilepsy treated with the MAD at our hospital between January 2008 and December 2012 is presented. Medical records of nine patients with refractory epilepsy treated with the MAD were reviewed. Clinical characteristics of patients are described in Table 1. One of the patients had started the CKD and switched to the MAD due to intolerance. In all cases, patients were evaluated before starting the diet, including the nutritional history, a daily record of seizure type and frequency, a clinical and anthropometric exam, and a lab test panel. Follow-up was performed with scheduled visits at one, three and six months after starting the diet, where adherence, tolerance and the seizure diary were evaluated.

Treatment effectiveness was measured at six months after starting the diet by establishing the number of seizures suffered. Such clinical control was classified as follows: 1) excellent control: if seizure control was absolute $(100 \%)$; 2) very adequate control: a reduction of more than $90 \%$ in the number of seizures; 3 ) adequate control: a reduction between $50-90 \%$ in the number of seizures; 4) regular control: a reduction of $<50 \%$ in the number of seizures; 5) no effect: no change 
in the number of seizures; and 6) negative effect: increased number of seizures. ${ }^{8}$

If patients showed a reduction of more than $50 \%$ in the number of seizures at six months, the diet was considered effective and they remained on it for two years; then patients were controlled at 12, 18 and 24 months. Those patients who did not show this reduction were immediately withdrawn from the diet.

Out of the nine patients, two had a very adequate control of seizures, four had an adequate control, two had a poor control, and only one had no response. No patients worsened compared to diet initiation. Table 1 shows seizure characteristics for each patient and the absolute frequency of seizures prior to the MAD and at six months after having started it.

The response observed by type of epileptic syndrome was as follows:

- Of patients with focal seizures (six): one had a very adequate control, three had an adequate control, one had a regular control, and one had no effect; therefore, no significant difference was observed in seizure control in this group.

- Of patients with Lennox-Gastaut syndrome (two): one had a very adequate control and one had a regular control.

- The patient with Dravet syndrome had an adequate control of seizures.

Out of nine patients, six had seizure reduction of at least $50 \%$. Patients who achieved a reduction in the number of seizures continued with no modifications observed in the different followups over the two year treatment with the MAD.

Adverse events included weight loss, hypercholesterolemia, sporadic self-limited diarrhea, and hypokalemia. These events were reverted and none represented an indication for diet discontinuation (see Table 1).

Four patients are currently on the MAD and three completed two years on the MAD with no relapse after treatment discontinuation. Two patients were on the MAD for six months only because they showed no response; and diet compliance was adequate in all patients.

\section{DISCUSSION}

The Atkins diet was developed in the 1970s by Dr. Robert Atkins for the treatment of obesity. Since it was similar to the principles proposed by the CKD, but less stringent, the Johns Hopkins Epilepsy Center started using it for the first time in 2001 for drug-resistant epilepsy.

The first publications on the MAD are from 2003 and 2006, 5,7 and describe series of cases with a favorable effect on the control of seizures. In $2006,{ }^{5}$ a prospective study was conducted; it included 16 patients treated with the MAD, with a mean age of 6.5 years old. After six months on the MAD, the percentage of seizure control was evaluated. Results showed that 12 patients had a seizure reduction of over $50 \%$, and of them, six had a reduction of over $90 \%$. The effectiveness of the MAD was assessed in a recent publication of a double-blind study on patients with refractory epilepsy on the diet. Patients were randomly enrolled for three months on the MAD or on a normal diet; subsequently, results showed that the MAD had been effective in reducing the number of seizures with a few adverse events, with a statistically significant difference between both groups. ${ }^{9}$

The differences between the CKD and the MAD basically lay on their nutrient composition and, therefore, their tolerability. Fat intake in the MAD is $60 \%$, while it accounts for $90 \%$ of total energy intake in the CKD. Unlike the CKD, no hospitalization is required in order to start the MAD. Foods are measured using carbohydrate tables, making it unnecessary to actually weigh foods, which should be strictly done with the CKD. Family members are trained on how to implement the MAD during outpatient visits. On the MAD, proteins are freely consumed, therefore preventing non compliance with the diet due to lack of satiety. The MAD can be a treatment option forthose patients (adolescents and adults) who cannot access a ketogenic diet center or who have behavioral disturbancesthat prevent them from starting or remaining on the CKD (lack of satiety, dietary transgression, anorexia). ${ }^{8-13}$

The MAD could be considered a second-line option for patients who showed poor adherence to the CKD (poor tolerance to calorie restriction) and who also comply with some of the previously described criteria, and for those patients who have epileptic encephalopathies, ${ }_{1}^{13}$ such as West syndrome, Lennox-Gastaut syndrome, Dravet syndrome, and symptomatic focal seizures.

The implementation of both the CKD and the MAD requires a multidisciplinary medical team made up of nutrition and neurology specialists to adequately follow-up patients and to achieve an suitable treatment adherence.

In our group, nine patients had similar results to those published by other authors in terms of adequate adherence, tolerance and control of seizures. None of the patients had severe adverse 
TABLE 1. Sample clinical characteristics

\begin{tabular}{|c|c|c|c|c|c|c|c|}
\hline Case & $\begin{array}{c}\text { Age } \\
\text { (years)/sex }\end{array}$ & $\begin{array}{l}\text { Type } \\
\text { of seizure }\end{array}$ & Drugs & $\begin{array}{c}\text { Monthly seizures } \\
\text { before/after } \\
\text { the MAD }\end{array}$ & $\begin{array}{l}\text { Reduction in } \\
\text { the number } \\
\text { of seizures }\end{array}$ & $\begin{array}{l}\text { Adverse } \\
\text { events }\end{array}$ & $\begin{array}{c}\text { Time } \\
\text { on MAD }\end{array}$ \\
\hline 1 & 5 / Female & $\begin{array}{l}\text { - Focal motor } \\
\text { - Generalized } \\
\text { (tonic-clonic) }\end{array}$ & $\begin{array}{l}\text { Topiramate } \\
\text { Levetiracetam } \\
\text { Valproic acid }\end{array}$ & $240 / 90$ & $50-90 \%$ & No & 2 years \\
\hline 2 & 12 / Male & $\begin{array}{l}\text { Generalized } \\
\text { - Atonic } \\
\text { - Tonic } \\
\text { - Atypical } \\
\text { absence }\end{array}$ & $\begin{array}{l}\text { Clobazam } \\
\text { Lamotrigine } \\
\text { Topiramate } \\
\text { Levetiracetam } \\
\text { Rufinamide }\end{array}$ & $\begin{array}{c}60 / 40 \\
900 / 450\end{array}$ & $0-50 \%$ & $\begin{array}{c}\text { Mild } \\
\text { hypokalemia }\end{array}$ & 2 years \\
\hline 3 & 20 / Female & $\begin{array}{l}\text { - Focal motor } \\
\text { - Focal, } \\
\text { secondarily } \\
\text { generalized }\end{array}$ & $\begin{array}{l}\text { Levetiracetam } \\
\text { Clobazam } \\
\text { Felbamate } \\
\text { Clobazam }\end{array}$ & $150 / 30$ & $50-90 \%$ & $\begin{array}{l}\text { Weight loss, } \\
\text { BMI }=23, \\
\text { previous }=26\end{array}$ & $\begin{array}{l}\text { Ongoing } \\
\text { (total: } \\
3 \text { years) }\end{array}$ \\
\hline 4 & 20 / Female & $\begin{array}{l}\text { Focal motor } \\
\text { - Focal, } \\
\text { secondarily } \\
\text { generalized }\end{array}$ & $\begin{array}{c}\text { Felbamate } \\
\text { Lamotrigine }\end{array}$ & $6 / 6$ & $0 \%$ & $\begin{array}{l}\text { Weight loss, } \\
\text { BMI }=19, \\
\text { previous }=21\end{array}$ & 6 months \\
\hline 5 & $21 /$ Male & - Focal motor & $\begin{array}{c}\text { Diphenylhydantoin } \\
\text { Clobazam } \\
\text { Oxcarbazepine }\end{array}$ & $8 / 6$ & $0-50 \%$ & No & 6 months \\
\hline 6 & 15 / Female & $\begin{array}{l}\text { Generalized } \\
\text { - Myoclonic } \\
\text { - Absence } \\
\text { - Tonic-clonic }\end{array}$ & $\begin{array}{l}\text { Valproic acid } \\
\text { Levetiracetam }\end{array}$ & $90 / 20$ & $50-90 \%$ & No & $\begin{array}{l}\text { Ongoing } \\
\text { (total: } \\
1 \text { year) }\end{array}$ \\
\hline 7 & 15 / Female & $\begin{array}{l}\text { Generalized } \\
\text { - Atypical absence } \\
\text { - Tonic-clonic }\end{array}$ & $\begin{array}{l}\text { Phenobarbital } \\
\text { Diphenylhydantoin } \\
\text { Oxcarbazepine } \\
\text { Lamotrigine } \\
\text { Valproic acid }\end{array}$ & $200 / 10$ & $+90 \%$ & No & $\begin{array}{l}\text { Ongoing } \\
\text { (total: } \\
1 \text { year) }\end{array}$ \\
\hline 8 & 9 / Female & $\begin{array}{l}\text { - Focal motor } \\
\text { - Focal, } \\
\text { secondarily } \\
\text { generalized }\end{array}$ & $\begin{array}{l}\text { Lacosamide } \\
\text { Topiramate } \\
\text { Phenobarbital } \\
\text { Valproicacid }\end{array}$ & $\begin{array}{l}150 / 5 \\
2 / 0\end{array}$ & $+90 \%$ & $\begin{array}{l}\text { Weight loss } \\
\text { BMI = 17, } \\
\text { previous 20, } \\
\text { diarrhea }\end{array}$ & $\begin{array}{l}\text { Ongoing } \\
\text { (total: } \\
1 \text { year) }\end{array}$ \\
\hline 9 & 17 / Male & - Focal motor & $\begin{array}{l}\text { Phenobarbital } \\
\text { Lamotrigine } \\
\text { Clobazam } \\
\text { Valproic acid } \\
\text { Topiramate }\end{array}$ & $20 / 8$ & $50-90 \%$ & $\begin{array}{l}\text { Increased } \\
\text { cholesterol }\end{array}$ & $\begin{array}{l}\text { Ongoing } \\
\text { (total: } \\
1 \text { year) }\end{array}$ \\
\hline
\end{tabular}

events. Those patients who succeeded with the diet were able to complete the treatment after two years. No patients worsened during treatment.

We believe that the MAD should be considered a treatment option, especially in adolescents and adults with refractory epilepsy.

\section{Acknowledgments}

To Luis Panico, M.D., who introduced and promoted this treatment in Argentina, for his selfless and patient help.

\section{REFERENCES}

1. Kwan P, Arzimanoglou A, Berg A, Brodie MJ, et al. Definition of drug resistant epilepsy: consensus proposal by the ad hoc Task Force of the ILAE Commission on Therapeutic Strategies. Epilepsia 2010;51(6):1069-77.

2. Freeman JM, Vining EP, Kossoff EH, Pyzik PL, et al. A blinded, crossover study of the efficacy of the ketogenic diet. Epilepsia 2009;50(2):322-5.

3. Bough KJ, Rho JM. Anticonvulsant mechanisms of the ketogenic diet. Epilepsia 2007;48(1):43-58.

4. Kossoff EH, Krauss GL, McGrogan JR, Freeman JM. Efficacy of the Atkins diet as therapy for intractable epilepsy. Neurology 2003;61(12):1789-91. 
5. Kossoff EH, McGrogan JR, Bluml RM, Pillas DJ, et al. A modified Atkins diet is effective for the treatment of intractable pediatric epilepsy. Epilepsia 2006;47(2):421-4.

6. Sharma S, Sankhyan N, Gulati S, Agarwala A. Use of the modified Atkins diet for treatment of refractory childhood epilepsy: A randomized controlled trial. Epilepsia 2013;54(3):481-6.

7. Neal EG, Chaffe H, Shawartz RH, Lawson MS, et al. The ketogenic diet for the treatment of childhood epilepsy: a randomised trial. Lancet Neurol 2008;7(6):500-6.

8. Kossoff EH, Dorward JL. The Modified Atkins Diet. Epilepsia 2008;49(suppl 8):37-41.

9. Lee PR, Kossoff EH. Dietary treatments for epilepsy: management guidelines for the general practitioner. Epilepsy Behav 2011;21(2):115-21.
10. Kossoff EH. Intractable childhood epilepsy: choosing between the treatments. Semin Pediatr Neurol 2011;18(3):145-9.

11. Miranda MJ, Mortensen M, PovisenJH, Nielsen H, Beniczky S. Danish study of a Modified Atkins diet for medically intractable epilepsy in children: Can we achieve the same results as with the classical ketogenic diet? Seizure 2011;20(2):151-5.

12. Auvin S. Should we routinely use modified Atkins diet instead of regular ketogenic diet to treat children with epilepsy? Seizure 2012;21(4):237-40.

13. Lee PR, Kossoff EH. Dietary treatments for epilepsy: management guidelines for the general practitioner. Epilepsy Behav 2011;21(2):115-21. 